\title{
Correction to: prospective cost and environmental impact assessment of battery and fuel cell electric vehicles in Germany
}

\section{Kai Bekel ${ }^{1} \cdot$ Stefan Pauliuk ${ }^{1}$}

Published online: 14 February 2020

C) Springer-Verlag GmbH Germany, part of Springer Nature 2020

Correction to: The International Journal of Life Cycle Assessment(2019) 24:2220-2237.

https://doi.org/10.1007/s11367-019-01640-8

The original version of this article unfortunately contained a mistake. Electronic Supplementary Material 1 was incorrect. The correct version is linked in the online version of this correction.

Electronic supplementary material The online version of this article (https://doi.org/10.1007/s11367-020-01729-5) contains supplementary material, which is available to authorized users.

The online version of the original article can be found at https://doi.org/ $10.1007 / \mathrm{s} 11367-019-01640-8$

Kai Bekel

Kai.bekel@web.de

1 Industrial Ecology Freiburg, Faculty of Environment and Natural Resources, University of Freiburg, 79106 Freiburg, Germany 